\title{
ACCESS TO AND INVESTMENT OF FORMAL MICRO CREDIT BY SMALL HOLDER FARMERS IN ABIA STATE, NIGERIA. A CASE STUDY OF ABSU MICRO FINANCE BANK, UTURU
}

\author{
C.O. Anyiro ${ }^{1}$ and B.N. Oriaku ${ }^{1}$
}

\begin{abstract}
Inadequate capital is a major problem confronting small-scale enterprises including farmers in Nigeria, despite the fact that small scale farmers produce the bulk of the food consumed locally and some export crops which generate foreign exchange to the country. Micro credit is a powerful anti poverty tool that has demonstrated relevance to people on six (6) continents and in nearly every country. Consequent upon the foregoing, this study determined access and investment of formal micro credit by small holder farmers in Abia state, Nigeria. A case study of Abia State University Micro Finance Bank Micro Finance Bank, Uturu (ASUMFB). Specifically, it sought to describe the socio-economic characteristics of loan beneficiary; to examine demand for micro credit by comparing the amount of formal loans applied for with the amount approved and the amount actually received by the farmers; to determine the uses of micro credit by small farmer loan beneficiaries; to determine factors that influence access to micro credit in micro finance banks. Purposive sampling technique was used to select 96 loan beneficiaries. Instrument of data collection was through a set of structured and pre-tested questionnaire. The study employed descriptive statistics and Probit regression model as analytical tools. The results of the Probit analyses showed that the coefficient of age, education, farm income, extension contact and distance between home and loan source were statistically significant at one percent probability level while farming experience and farm size were at 5 percent level. It was however recommended that Micro finance banks should ensure timely disbursement of loans to young, experienced and educated farmers who are more likely to utilize resources efficiently.
\end{abstract}

Key words: Access, Investment, Micro Credit

\section{INTRODUCTION}

Access to credit is regarded as one of the key elements in raising agricultural productivity (DBSA, 2005). Micro credit is the name given to extremely small loans made to poor borrowers. It enhances the production capacity of the poor resource farmers through financial investment in their human and physical capital (okurut et al, 2004).

Availability of adequate and timely credit will help in expanding the scope of operation and adoption of new technology as well as enhancing the purchase and use of some improved inputs which are not available on the farm. Oladeebo and Oladeebo (2008). For a farmer to derive benefit from any institutional credit, the size of the loan, the process of granting such loan, timeliness in disbursement and repayment are important, apart from level of education, marital status and family size (Nweze, 1991).

One of the problems confronting smallscale enterprises including farmers in Nigeria is inadequate capital despite the fact that small scale farmers produce the

\footnotetext{
${ }^{1}$ Department of Agricultural Economics and Extension, Abia State University Uturu, Uahia Campus, Umuahia, Abia State.
} 
bulk of the food consumed locally and some export crops which generate foreign exchange to the country Ojo (1998). This situation has attracted the attention of Nigerian government and this has led the federal government of Nigeria into the creation of specialized institution such as the Nigeria Agricultural and Cooperative Bank (NACB) which later translated into the Nigeria Agricultural Cooperative and Rural Development Bank (NACRDB), the Nigerian Agricultural Credit Guarantee Scheme Fund (ACGSF), Community Banks (CB) and encouraging establishment of Co-operative Societies to cater for credit needs in the agricultural sector (Oladeebo, 2003). Government had also mandated the commercial banks in Nigeria to give credit facilities to the agricultural sector of the country (Ajakaiye, 1998).

In spite of all these policies instituted by the Federal Government, there seems to be no remarkable improvement in the financial position of bulk of small farmers in Nigeria. Food prices have been rising persistently, and there have been greater shortage of food, food stuffs and raw materials. There have been no improvements in the food production methods and techniques of the rural small farmers. A major challenge facing many developing countries especially in Africa is devising appropriate development strategies that capture financial services to small scale farmers who constitute about 70 percent of the population (Oriaku, 2010).

\section{Research Objectives}

The specific objectives are as follows;

1. to determine the socio economic characteristics of farmer borrowers from Abia State University Micro Finance Bank.

2. to examine demand for micro credit by comparing the amount of formal loans applied for with the amount approved and the amount actually received by the farmers from Abia State University Micro Finance Bank.

3. to determine the uses of micro credit by small farmer loan beneficiaries from ABSU Micro Finance Bank.

4. to determine factors that influence access to micro credit in micro finance banks.

Hypotheses tested: The following hypotheses were tested.

$\mathrm{Ho}_{\mathbf{1}}$ : Access to micro credit is positively influenced by educational Level of farmer, farm size, membership of farmers associations, Farming experience, extension contact and farm income and is negatively influenced by gender and age.

\section{MATERIALS AND METHODS}

The study was carried out at Abia State University Micro finance Bank. This Microfinance Bank is an investment for members of the University Community. It was purposively selected on the basis of its proximity and easy access to the required data. It was established in the year 1986 as Abia state University Community Bank, and later changed to a Micro finance bank in line with CBN reforms in January 2007. The Micro finance bank is located at a strategic location at the entrance of the University gate at Uturu. Uturu Community is located in Isuikwuato. The major occupation of the people is farming (Oriaku, 2010). The community has hilly and plain topography, with Guinea Savannah vegetation. Uturu is typically an agrarian community which has both the agro climatic and soil type conditions conducive to the cultivation of arable crops such as maize, cassava, yam, tomatoes, and cowpea. Small scale production and processing are also common in the area. The area is accessible by road and rail. The people of Uturu community patronize Abia State 
University Micro Finance Bank because of its proximity. Random sampling techniques were used in the selection of the respondents. A list of small holder farmers who have benefited from the micro credit lending of ABSU Micro finance Bank was collected from the bank, to serve as a sampling frame. From this list, 96 farmer credit beneficiaries were selected following simple random sampling technique. Instrument of data collection was a well structured questionnaire. Objectives (i), (ii) and (iv) were analyzed with the use of descriptive statistics such as frequency distribution tables, percentage and mean, while objective (iii) was captured using Probit model.

\section{Model Specification}

Probit model is appropriate when the response takes one of only two possible values representing presence or absence. This is expressed as (Gujarati, 2003);

$\mathrm{P}_{\mathrm{i}[\mathrm{Y}=1]=[\mathrm{Fzi}]}$

Where $\mathrm{Z}_{\mathrm{i}}=\beta \mathrm{o}+\beta_{1} \mathrm{X}_{\mathrm{i}}$

$\mathrm{Y}_{\mathrm{i}}=\beta_{1}+\beta_{2} \mathrm{X}_{2 \mathrm{i}}+\ldots \ldots \ldots \ldots \ldots \ldots \ldots+\beta_{\mathrm{k}} X_{\mathrm{ki}}+\mu$

$Y^{*}$ is unobserved but $Y_{i}=0$ if $y_{i} *<0, Y_{i}=1$ if $y_{i}^{*} \geq 0$

$\mathrm{P}\left(\mathrm{y}_{\mathrm{i}}=1\right)=\mathrm{P}\left(\mathrm{y}_{\mathrm{i}}^{*} \geq 0\right)$

$=\mathrm{P}\left(\mu_{1} \geq-\beta_{1}-\beta_{2} \mathrm{X}_{2 \mathrm{i}}-\cdots \cdots \cdots \cdots \cdot \beta_{\mathrm{k}} \mathrm{X}_{\mathrm{ki}}\right)$

$\mathrm{i}=1,2 \ldots \ldots \ldots . .96$ farmers

Where $\mathrm{Y}_{\mathrm{i}}=$ farmers access to micro credit.

(Dichotomous variable $1=$ yes; $0=\mathrm{No}$ )

$\beta=$ A vector of unknown coefficients.

$\mathrm{X}_{\mathrm{i}}=$ vector of characteristics of ith individual, and is the independent variables, which are defined as follows;

$$
\begin{aligned}
& \mathrm{X}_{1}=\text { Age of farmer }(\text { years }) \\
& \mathrm{X}_{2}=\text { Educational level (years) } \\
& \mathrm{X}_{3}=\text { Farming experience (years) } \\
& \mathrm{X}_{4}=\text { House hold size (number) } \\
& \mathrm{X}_{5}=\text { Gender }(1=\text { male; } 0=\text { female) } \\
& \mathrm{X}_{6}=\text { Marital status } \\
& \mathrm{X}_{7}=\text { Farm income (Naira) } \\
& \mathrm{X}_{8}=\text { Extension contact (no of time) } \\
& \mathrm{X}_{9}=\text { Farm size (hectares) } \\
& \mathrm{X}_{10}=\text { Membership of farmers association } \\
& (1=\text { member; } 0=\text { otherwise) } \\
& \mathrm{X}_{11}=\text { Distance between Home and Source (kilometer) } \\
& \mu=\text { Error term }
\end{aligned}
$$

\section{RESULTS AND DISCUSSION}

The results of socio-economic characteristics of loan recipients are summarized in Table 1. The average age of farmers (loan beneficiaries) is 45 years. The implication of the result with respect to age implies that farmers were within the middle-aged groups which were still energetic and productive. This segment of the respondents within these mean ages is rational decision makers and time is still at their disposal to establish indelible reputation within the community. Credit institutions might be willing to give loan facility to young and dynamic farmers who are more likely to adopt new innovations 
than the older farmers (Oladeebo and Oladeebo, 2008).

The means values of 3 hectares and 5 years were obtained for farm size and years of experience with credit utilization respectively. The mean values obtained for farm size and years of experience with credit utilization respectively are indications of small scale nature of farming business and that farmers have not had a substantial years of experience in credit utilization (Obasi, 1991).

The average family size of 5 indicates moderate household size, this is expected because beneficiaries with large family sizes are likely to spend more of the loans in financing consumption and other basic house hold requirements than on farm production (Njoku and Odii ,1991).

Table 01 also shows that most of the respondents $(37.50 \%)$ had secondary school education, $26.0 \%$ of the respondents had primary education, and 29.20 of them had post secondary while only $7.3 \%$ of the respondents had no formal education. The results further showed that literate farmers (loan beneficiaries) in both categories of farmers grossly dominate the study area. The level of education attained by a farmer not only increases his/her farm productivity but also enhances ability to understand and evaluate new production technologies (Eze, 2007). Possession of literacy is one of the criteria for the procurement of formal credit from micro finance banks (Njoku and Odii, 1991).

Majority $(86.5 \%)$ of loan recipients are male. Majority $(86.5 \%)$ of loan recipients are male. This agrees with the findings of Olayede (2000) that small scale farming is majorly carried out mostly by males.

The distribution of the respondents according to the amount applied for, amount approved and received is shown in Table 02.

The table showed that majority of the respondents $44.79 \%$ applied for credit above hundred thousand naira ( $\$ 100,000$ or US\$625) but only $12.50 \%$ of them were disbursed. Almost half of the respondents $(48.97 \%)$ received below forty one thousand naira ( 41,000 or US $\$ 256$ ). This indicates that the farmer's credit demand is far higher than the supply. However, enquiries from management of Abia State University Micro finance bank showed that due to gross shortage of loanable funds, available funds were rationed among the numerous successful applicants (Oriaku, 2010).

The distribution of the farmer borrowers on the uses of micro credit is shown in the Table 3. The result indicated that $16.66 \%$ of the respondents (loan beneficiaries) used their loan for crop production only, $19.79 \%$ of them diversified the loan in crop and animal production, while $17.71 \%$ and $9.38 \%$ of the loan beneficiaries applied the loan on livestock production and fisheries respectively. Majority of the respondents $(36.46 \%)$ used the loan to expand the scope of their farming because of its benefit. This is in consonance with Oladeebo and Oladeebo (2008) that had similar result on the Determinants of Loan Repayment among Smallholder Farmers in Ogbomoso Agricultural Zone of Oyo State, Nigeria.

The results of probit regression analysis of the determinants of access to micro credit are shown in table 4 . The result revealed that the coefficient of age, education, farm income, extension contact and distance between home and loan source were statistically significant at $1.0 \%$ probability level while farming experience and farm size were significant at 5 percent level. 
Table 01: Socio-economic Characteristics of Farmer Borrowers from Abia State University Micro Finance Bank.

Socio-economic Variable

Mean values

\begin{tabular}{|c|c|c|c|c|c|}
\hline \multicolumn{4}{|l|}{ Mean age (years) } & \multicolumn{2}{|l|}{45} \\
\hline \multicolumn{4}{|l|}{ Household size } & \multicolumn{2}{|l|}{5} \\
\hline \multicolumn{4}{|l|}{ Farm size (ha) } & \multicolumn{2}{|l|}{3} \\
\hline \multicolumn{4}{|c|}{ Years of experience with credit utilization } & \multicolumn{2}{|l|}{5} \\
\hline \multicolumn{6}{|c|}{ Educational level (in \%) } \\
\hline \multicolumn{4}{|l|}{ None } & \multicolumn{2}{|l|}{7.3} \\
\hline \multicolumn{4}{|c|}{ Primary education } & \multicolumn{2}{|l|}{26.0} \\
\hline \multicolumn{4}{|c|}{ Secondary education } & \multicolumn{2}{|l|}{37.5} \\
\hline Post secondary e & & & & \multicolumn{2}{|l|}{29.2} \\
\hline \multicolumn{6}{|c|}{ Gender (in \%) } \\
\hline \multicolumn{4}{|l|}{ Male } & \multicolumn{2}{|l|}{86.5} \\
\hline \multicolumn{4}{|l|}{ Female } & \multicolumn{2}{|l|}{13.5} \\
\hline \multicolumn{6}{|c|}{ Source: Field survey Data, 2010} \\
\hline \multicolumn{6}{|c|}{$\begin{array}{l}\text { Table 02: Distribution of Respondents According to the Amount Applied for Amount } \\
\text { Approved and Received. }\end{array}$} \\
\hline \multirow[t]{2}{*}{ Size of loan ( } & \multicolumn{2}{|c|}{ Amount applied for } & Amount approved & \multicolumn{2}{|c|}{ Amount received } \\
\hline & & $\%$ & Frequency $\%$ & Frequency & $\%$ \\
\hline$\leq 20000$ & 5 & 5.20 & $10 \quad 10.42$ & 10 & 10.42 \\
\hline $21000-40000$ & 7 & 7.29 & 38.54 & 37 & 38.63 \\
\hline $41000-60000$ & 13 & 13.54 & 15.63 & 15 & 15.63 \\
\hline $61000-80000$ & 10 & 10.42 & 7.29 & 7 & 7.29 \\
\hline $81000-100000$ & 18 & 18.75 & 13.54 & 13 & 13.54 \\
\hline$>100000$ & 43 & 44.79 & 12.50 & 12 & 12.50 \\
\hline Total & 96 & 100 & 100 & 96 & 100 \\
\hline
\end{tabular}

Table 03: Distribution of Respondents by the uses of Micro Credit from ABSU Micro Finance Bank.

\begin{tabular}{lrcc}
\hline Enterprise & Frequency & Percentage \\
\hline Crop production only & 16 & 16.66 \\
Livestock production only & 17 & 17.71 \\
Crop and animal production & 19 & 19.79 \\
Fisheries & 9 & & 9.38 \\
Establishment of new farms & 35 & & 36.46 \\
\hline Total & & $\mathbf{9 6}$ & $\mathbf{1 0 0 . 0 0}$ \\
\hline
\end{tabular}

Source: Field Survey Data 2010.

The coefficient of education, farming experience extension contact, household

source were positive and significant at a size and distance between home and specific level except household size. More specifically, the coefficients of age, farm 
size, and marital status were negative. The coefficient of membership of co-operatives and gender possessed a negative sign. The chi square estimate of 22.520 is highly significant.

These Results revealed that variables with positive signs indicate that their higher values increase the chances that the farmers have to access credit and vice versa. More specifically, the negative coefficients of age (-0.0072) and farm size $(-0.0730)$ imply that the chances of the farmers in accessing credit decrease with age and farm size. Moreso, the negative sign of marital status (-0.0371) shows that the unmarried female farmers have chances of taking credit. The negative coefficients of gender (-0.0986) implies that the chances of the farmers in accessing credit decrease with gender, though it was not significant at any probability level.
Contrary to apriori expectation, the negative coefficient of membership of cooperatives (-0.0339) indicates that noncoperators have probability of accessing credit. It is likely that co-operative societies have not made the desired impact in the study area and as such account for the posture of the result. The sign identity of age makes sense for this study area and those with a similar setting as predominance of young farmers. This result is consistent with the findings of Sebopetji and Belete (2009). Although the negative coefficient of farm size $(-0.0730)$ is at variance with apriori expectation, it suggests efficiency in the use of land rather than expansion of cultivated areas as a necessary requisite that could increase chances of accessing credit (Nnadozie and Uzoigwe, 2002).

The chi square estimate of 22.520 is highly significant. As a measure of goodness of fit, it shows that the data set fit the regression line to a reasonably high level.

Table 04: Probit Regression Coefficient of Factor Affecting Access to Credit

\begin{tabular}{lcc}
\hline Variables & Estimated coefficient & Standard error \\
\hline Age & $-0.0072^{* * *}$ & 0.0021 \\
Education & $0.0148^{* * *}$ & 0.0010 \\
Faming exp & $0.0035^{* *}$ & 0.035 \\
House hold size & 0.0225 & 0.0248 \\
Gender & -0.0986 & 0.0689 \\
Marital status & -0.0371 & 0.1979 \\
Farm income & $0.0091^{* * *}$ & 0.0026 \\
Extension contact & $0.0624^{* * *}$ & 0.0135 \\
Farm size & $-0.0730^{* *}$ & 0.0364 \\
Membership of co-op & -0.0339 & 0.1197 \\
Distance btw & $0.0839^{* * *}$ & 0.0214 \\
Home\&Source & & 54 \\
Number of observation at one: & 42 \\
Number of observation at zero: & 220.520 \\
X(chi square) & &
\end{tabular}

Source: Computed from field survey data 2010

$* * *$ Variables significant at $1.0 \% * *$ Variables significant at $5.0 \% *$ Variables significant at $10.0 \%$ 


\section{CONCLUSIONS}

The result obtained in this study revealed that the chances of the farmers in accessing credit from the micro finance bank (Abia State University Micro finance bank) decreased with age and farm size. From the study, efficiency is suggested in the use of farm land rather than necessary requisite that could increase the chances of accessing loan. It was also discovered that non co-operators have increased probability of accessing credit. The chances of the farmers in accessing credit increases with educational attainment, farming experience, farm income, extension contact, distance between home and loan source as proved by the study.
Based on the findings of this study, it is recommended that micro finance banks should ensure timely disbursement of loans to young, experienced and educated farmers who are more likely to utilize resources efficiently, and repay loans promptly. Diversification of loans on profitable agricultural enterprise should be employed by farmer borrowers. A loan increment policy should be embarked by all financial institutions in order to satisfy the demands of farmer borrowers. Experts in the field of project evaluation, project appraisal monitoring and loan administration should be employed for effective supervision, loan utilization and loan recovery performance in micro finance banks.

\section{REFERENCES}

Ajakaiye, M.B. (1998). Financing Agricultural Programmes in Nigeria. The Role of the Nigeria Agricultural and Cooperative Bank Limited, Pp. 4-9 in Readings in Agricultural Finance, A. Okorie and M.O Ijere (Eds). Lagos: Longman.

Development Bank of South Africa (2005). Development Report 2005, Agriculture in South Africa's Second Economy (chapter7), W.dbsa.org/document/developmentreport/dev. Accessed 12/11/09

Gujarati D. (2003). Basic Econometrics. Tata Mc Graw Hill Edition.

Njoku, J.E and Odii M.A.C.A (1991), Determinants of loan repayment under the special emergency loan scheme(SCALS) In Nigeria. A case study of imo state. In African Review of money, Finance and banking. FIN Africa Italy

Nweze N.J.(1991) The Role of Women Traditional Savings and Credit Co-operative in Small Holder Farm Development in: Ogits, C.A (eds) Issues in Africa Rural Development, pp 234-236.

Nnadozie, A.K.O and Uzoigwe, J.I. (2002). Effectiveness of Local Sanctions on Agricultural Loan Recovery Under Community Banking in Enugu State. Journal of the Science of Agriculture, Food Technology and the Environment, 2(1): 56 - 62.

Ojo, M.O. (1998). Some Implications of Government Economic Policies for The Financing and Development of Agriculture in Nigeria, Pp. 16-24 in Readings in Agricultural Finance, A. Okorie and M.O Ijere (Eds). Lagos: Longman.

Obasi P.C. (1991). Resource use Efficiency in Food Crop production: A Case of Owerri Agricultural Zone of Imo State. MSc. Thesis University of Ibadan, Nigeria, 1991.

Ojo, M.O. (1998). Some Implications of Government Economic Policies for The Financing and Development of Agriculture in Nigeria, Pp. 16-24 in Readings in Agricultural Finance, A. Okorie and M.O Ijere (Eds). Lagos: Longman.

Okurut, N., A. Schoombee and S. Van dar Berg (2004). Credit Demand and rationing in the Informal Financial Sector in Uganda. Paper on the DPRU/Tips/Cornell Conference on African Development and Poverty reduction. 
Oladeebo J. O. and Oladeebo O. E. (2008). Determinants of Loan Repayment among Smallholder Farmersin Ogbomoso Agricultural Zone of Oyo State, Nigeria J. Soc. Sci., 17(1): 59-62

Oladeebo, O.E. (2003). Socio- Economic Factors . Influencing Loan Repayment Among Small Scale Farmers in Ogbomoso Agricultural Zone of Oyo State, Nigeria. Full Professional Diploma Project (unpublished), Department of Management Science, Ladoke Akintola University of Technology, Ogbomoso, 54p

Olayede R. (2000). Effectiveness of Development Interventios of Economic Empowerment on Rural Women in Ondo Nigeria. An Unpublished p.hD thesis submitted to the department of agricultural extension and rural Development, University of Ibadan, Ibadan.

Oriaku, B.N. (2010). Access to and Investment of Formal Micro credit by small holder farmers in Abia State, Nigeria. A case study of ABSU micro finance bank, Uturu. ". B. Agric. Thesis. Dept of Agricultural Economics and Extension, Abia State University Uturu.

Sebopetji T.O and Belete A. (2009). Application of Probit Analysis to Factors Affecting Small Scale Farmers Decision to take Credit: A case Study of the Greater Letaba Local municipality In south Africa. African Journal of Agricultural Research 4(8): 718-723. 